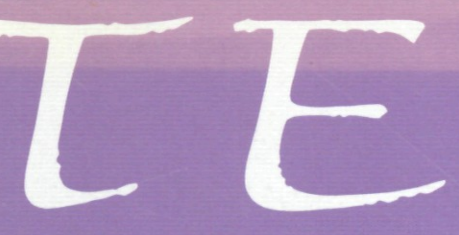

A Quarterly Review of Modern Music

No. 178 / September 1991

Webern, the BBC and the Berg Violin Concerto Lewis Foreman

Octaves in Webern's Bagatelles Regina Busch

Atonality, 12-Tone Music and the Third Reich Erik Levi

Gruber's Concertos Paul Driver

Performance Review: 'The Death of Klinghoffer' Jane Highfield

Performance Review: ‘Gawain’ Robert Samuels

Book Review: Glock's Autobiography Christopher Shaw

Record Review: Boulez's Webern Malcolm Hayes 
Lewis Foreman currently has three books in proof - an illustrated annotated edition of Arnold Bax's autobiography Farewell, My Youth (Scolar Press); the proceedings of the 1990 BMIC seminar on music publishing Lost and only Sometimes Found (British Music Society); and British Music 1885-1920 (Thames Publishing). His article in this issue is enlarged and updated from a paper first presented at the RMA Annual Conference of Music Research Students, 20 December 1985, at the University of Keele. An abridgement appeared in the booklet to the Continuum Records CD of the Krasner/ Webern performance of the Berg Concerto.

Regina Busch is Editor of the Alban Berg Gesamtausgabe in Vienna, and is working on a book about Anton Webern. Her article in this issue was originally published in the Swiss music journal Dissonanz (February 1991 issue), and is translated here by their kind permission.

Erik Levi is a professional accompanist, reviewer and lecturer in music at Royal Holloway and Bedford New College, University of London, and is currently writing a book on music in Nazi Germany to be published by Macmillan.

Paul Driver is a regular music critic for the Sunday Times.

Jane Highfield is a freelance singer, lecturer and writer. For many years she was a professor at the R.A.M. and is currently vocal coach to the National Youth Choir of Great Britain. Her work as a concert/opera singer has taken her to many parts of the world, including Bayreuth, Tokyo, Monte Carlo and Brussels.

Robert Samuels is currently teaching in the Music Department of Manchester University.
Geoffrey Elborn, whose books include biographies of Edith Sitwell and Francis Stuart, is currently contriburing entries to a dictionary of 20 th-century literature.

Malcolm Hayes is a music critic for The Daily Telegraph and Sunday Telegraph; he is currently composing some settings of Antonio Machado for voices and bells, in memory of Luigi Nono.

David Matthews has just completed his Sixth String Quartet for the Brindisi Quartet, who will give the first performance at the Little Missenden Festival on 19 October.

Ian Kemp is Professor of Music at Manchester University.

Gerard McBurney's reconstruction of Shostakovich's musichall revue Uslovno ubiti (Conditionally Killed) will be premièred by the CBSO under Gennadi Rozhdestvensky in November.

Antony Bye is Deputy Editor of the Musical Times.

Andrew Kemp is head of Copyright for Boosey \& Hawkes Music Publishers, and a regular opera reviewer for $C D$ Review.

Christopher Fox's composition for wind band, Some Creation Myths, was premièred at a New Macnaghten Concert in Blackheath in March by the Composers Ensemble conducted by Stefan Asbury.

Steve Sweeney Tumer lives in Glasgow and is currently completing a dissertation on contemporary musical aesthetics.

\section{ISSN 0040-2982}

Tempo 1991 Boosey \& Hawkes Music Publishers Ltd, Library of Congress Catalog Card No. 50-367000.

Printed in England by Graphikon Ltd, for Boosey \& Hawkes Music Publishers Ltd, 295 Regent Street, London W1R 8JH. U.S. address: 24 East 21st Street, New York NY10010, U.S.A.

Design: Gerald Cinamon. 

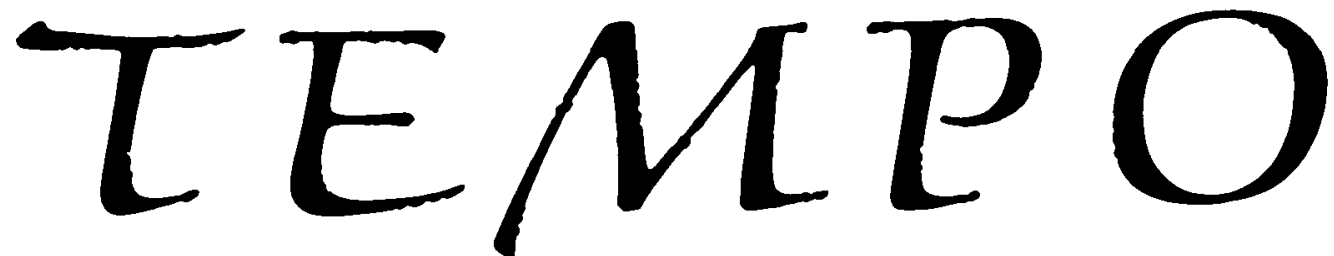

Editor Calum MacDonald

Advisory Editor David Drew

No. 178 / September 1991

Webern, the $\mathrm{BBC}$ and the Berg Violin Concerto Lewis Foreman 2

Octaves in Webern's Bagatelles Regina Busch 12

Atonality, 12-Tone Music and the Third Reich Erik Levi 17

Gruber's Concertos Paul Driver 22

First Performances:

'The Death of Klinghoffer' Jane Highfield

Birtwistle's 'Gawain' Robert Samuels 32

David Matthews's Fourth Symphony Guy Rickards 33

Donna Amato Geoffrey Elborn 33

\section{Book Reviews:}

Glock's 'Notes in Advance' Christopher Shaw 38

Nattiez's 'Music and Discourse' Robert Samuels 39

Boulez; Cage; Cunningham; Johns Steve Sweeney Turner 40

Maderna and Berio Peter Palmer 41

Enescu Calum MacDonald 42

Record Review:

Complete Weberns Malcolm Hayes 45

Berthold Goldschmidt David Matthews 46

Kurt Weill discs Ian Kemp 47

Collins Classics Britten Edition Peter Palmer 48

Robert Simpson quartets and band music Guy Rickards $\quad 50$

Malcolm Arnold Symphonies Martin Anderson 51

Hall / Goehr / Wood etc. Antony Bye 52

John Casken's 'Golem' Matthew Rye 53

Finnish Operas Andrew Kemp 55

Electroacoustic Music Christopher Fox 56

American miscellany Bret Johnson 57

Isang Yun John Warnaby 60

Gubaidulina and others Gerard McBurney 61

Nowowiewski organ music Martin Anderson

Letter to the Editor Guy Rickards 67

News Section 67

R.M.A. Conference 'Music and Politics' Malcolm Miller 70 